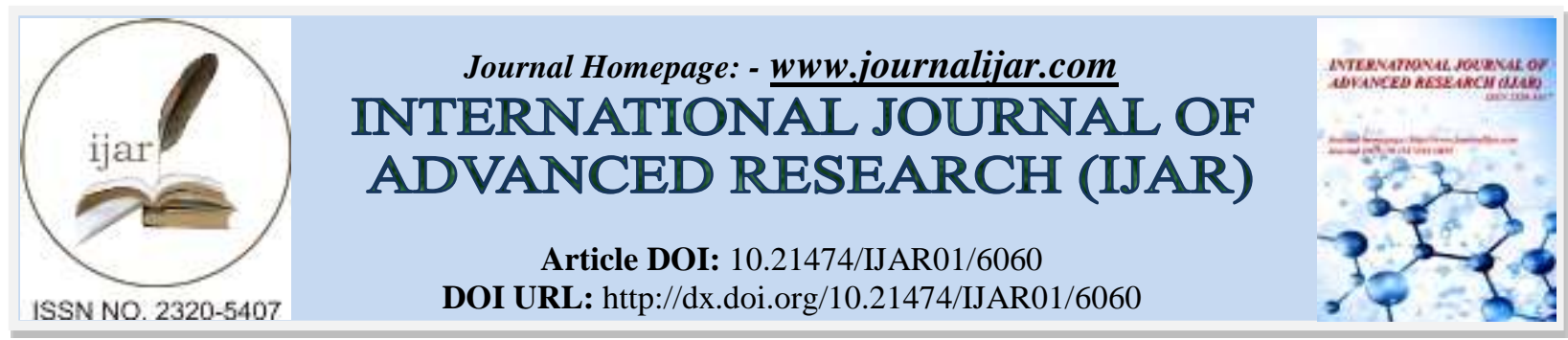

RESEARCH ARTICLE

\title{
EFFECT OF SPLINTING AND NON SPLINTING OF IMPRESSION TRANSFER DURING IMPRESSION MAKING ON THE FIT OF MULTI-IMPLANT SUPPORTED FIXED FULL ARCH FRAMEWORKS. SYSTEMATIC REVIEW AND META-ANALYSIS.
}

\section{Zakaria $A^{1}$, Kaddah $\mathrm{AF}^{2}$, Fayyad $\mathrm{AE}^{3}$ and $\mathrm{Al}$-quitaiby $A Y^{4}$.}

1. Zakaria A: Ph.D researcher, removable prothodontic department, Faculty of dentistry, Cairo University.

2. Kaddah AF: Professor of removable prothodontic, Faculty of dentistry, Cairo University.

3. Fayyad AE: Associate Professor of removable prothodontic, Faculty of dentistry, Cairo University.

4. Al-quitaiby AY: Ph.D removable prothodontic, Faculty of dentistry, Cairo University.

\section{Manuscript Info}

\section{Manuscript History}

Received: 14 October 2017

Final Accepted: 16 November 2017
Published: December 2017

\begin{abstract}
Statement of problem: The best impression technique should be followed during construction of prosthesis to eliminate poor fit of frameworks connected to implant to decrease undue stresses on the various elements.

Purpose: The purpose of this review was to evaluate clinical studies comparing splinted and nonsplinted impression techniques regarding passive fit

Materials and methods: An electronic search was performed in November 2017 of MEDLINE, and Cochrane Library databases with the key words implant, implants, impression, and impressions. To be included, the study had to investigate the passive fit of implant prosthesis. In addition, a hand search was performed to enrich the results for the time period from January 1980 to May 2017. After executing the search strategies, 3 articles were selected to be included in the review process.

Results All of the selected articles were in clinical studies. Two studies preferred splinted over nonsplinted impressions. One study reported no difference. The meta-analysis of the three trials regarding framework fitting comparing splinted and non-splinted impression showed statistically non-significant more risk of misfit in none splinted technique when compared to splinted technique.
\end{abstract}

Copy Right, IJAR, 2017,. All rights reserved.

\section{Introduction:-}

An accurate and passively fitting prosthesis is suggested as an important requirements for long term implant success. ${ }^{1-2}$ Poorly fitted prosthesis can result in implants failure or aggravate marginal bone loss in addition to mechanical problems like screws loosening and fatigue fractures of implant components which increase cost and decreases patient satisfaction. ${ }^{10-11}$

The accurate record and transfer of the implants position and relation from the patient to the master cast is the first step to get passive fit of prosthesis framework. ${ }^{3-4}$ In regard to splint the impression copings, there are many opinions

Corresponding Author:- Zakaria A.

Address:- Zakaria A: Ph.D researcher, removable prothodontic department, Faculty of dentistry, Cairo 
exist since Brånemark et al. that emphasize the importance of impression copings splinting together before impression taking. ${ }^{5}$

The best splinting technique should be followed during construction of prosthesis to eliminate poor fit of frameworks connected to implant to decrease unequal distribution of occlusal stresses on the various elements.

Many studies compared different impression transfer splinting techniques to get accurate transfer of implants spatial relationships. Mainly there are two types of impression splinting either direct (primary) or indirect (secondary). In regard to direct splinting, the main reason of distortion with resin possibly occurred by the residual polymerization shrinkage. ${ }^{6-7}$ Some authors revealed that, indirect splinting offers more precise relation transfer while others deduced that there is no significant difference between direct and indirect splinting of impression transfer. ${ }^{8-9}$ So that, will the use of splinting technique offers a better spatial implant relation transfer and accordingly better prosthesis fit than nonsplinting technique or not?

\section{Materials and Methods:-}

The design of the meta-analysis was registered on the international prospective register of systematic reviewers (PROSPERO), the registration number being CRD42017072172.

The present review was performed in strict accordance with the Preferred Reporting Items for Systematic Reviews and Meta-Analyses (PRISMA) guidelines ${ }^{12}$.

\section{Eligibility criteria:-}

Included studies:-

RCTs, in which splinted transfer coping impression technique were compared to nonsplinted technique.

\section{Participants:-}

Patients with implants supported fixed prosthesis

\section{Types of interventions:-}

Splinted impression technique.

Non-splinting of impression transfer.

\section{Outcome measure:-}

Passive fit of the framewok or verification jig to evaluate accuracy of the impression technique

\section{Information Sources:-}

Search Strategy for Identification of Studies

\section{Electronic search:-}

Medline via the PubMed database and the Cochrane Central Register of Controlled Trials (CENTRAL) of the Cochrane Collaboration were used as electronic databases besides searching of the following related journals; Journal Of Dentistry And Oral Implants, European Journal Of Oral Implantology , Journal Of Oral Rehabilitation, Journal Of Prosthodontics, Journal Of Investigative And Clinical Dentistry, Clinical Implant Dentistry And Related Research, Clinical Oral Implants Research, Periodontology 2000, Journal Of Clinical Periodontology, Journal Of Periodontology, The International Journal Of Periodontics And Restorative Dentistry, International Journal Of Oral And Maxillofacial Surgery, Clinical Oral Implants Research, Journal Of Dental Implants, The Journal Of Implant \& Advanced Clinical Dentistry, International Journal Of Implant Dentistry, Journal Of Oral Implantology, International Journal Of Clinical Implant Dentistry, Journal Of Periodontology \& Implant Dentistry, Implant Dentistry. The literature search was accomplished with a personal computer on articles published in English up to and including November 2017.

The reference lists of all identified articles related to the topic were subjected to close scrutiny. The authors attempted to search for the maximum possible number of proceedings of past workshops, position papers, and theses. Whenever deemed essential, missing, unclear, or unpublished data was sought by contact with authors. 


\section{Search Strategy:-}

Two reviewers independently performed the search (Zakaria A and Fayyad AE). Combinations of controlled terms $(\mathrm{MeSH})$ and keywords were used whenever possible. The terms searched in PubMed \& Cochrane were $(((()(()(((($ nonsplinted) OR nonsplinted implant impression) OR Non splinting) OR non-splinted) OR non-splinted impression transfer) OR open tray impression) OR non-splinted technique) OR non-splinted impression) OR nonsplinted implant impression) OR non-splinted impression transfer) OR non-splinted impression coping)) AND $(((()((()(()(($ Splinted) OR Direct splinting) OR primary splinting) OR duralay splinting) OR resin splinting) OR resin bars) OR impression transfer splinting) OR open tray impression) OR acrylic resin splint) OR splinting) OR splinted technique) OR splinted impression) OR splinted implant impression) OR splinted impression transfer) OR splinted impression coping $))$ AND $((()((()(()((()((($ Implant) OR Implants) OR oral implant) OR implant supported fixed prosthesis) OR Multi-unite implant impression) OR implant level impression) OR implant impression) OR edentulous patient) OR abutment level impression) OR Screw retained implant) OR implant prosthesis) OR dental implants) OR implant prosthesis) OR implant prosthesis framework) OR cement retained implant prosthesis) OR screw retained implant prosthesis) OR screw retained prosthesis) OR implant retained bridge) OR cement screw retained implant) OR fixed implant prosthesis)

\section{Selection of the Studies:-}

Papers were included if the following criteria were fulfilled: dental publications in English, randomized controlled trials, a minimum sample size of 10 patients. The Pubmed search resulted in 196 articles, Cochrane search resulted in 88 articles in addition to 2 record identified from other sources. After the initial screening, 16 publications were selected for additional evaluation of the full-text version for being directly related with the aim of the present study. Finally, 3 RCTs fulfilled were included and 13 articles were excluded. Finally a total of 3 publications were selected for data analysis.

\section{Data Collection and Analyses:-}

Two reviewers (Zakaria A and Fayyad AE) evaluated the relevance of the studies by a first selection based on the title and abstract. Disagreement about whether a study should be included for full inspection was resolved by a consensus discussion. The final full texts were included only after a mutual agreement between the two reviewers and any disagreements were resolved by mutual discussion; if not a third reviewer (Kaddah AF) was consulted.

\section{Data Extraction and Management:-}

Data were extracted independently by the reviewers whose were reciprocally blinded to each other's extraction. The name of author(s), publication year, participants, intervention type, no. of implants and position, outcome measures/variables and outcomes of studies were extracted (table 1).

\section{The Quality Assessment:-}

Assessing risk of bias of individual studies was accomplished according to the Cochrane Collaboration tool for assessing the risk of bias (Table 8.5.a in the Cochrane Handbook for Systematic Reviews of Interventions). The domains that were assessed for each included study are: random sequence generation, allocation concealment, blinding of participants and personnel, blinding of outcome assessment, incomplete outcome data, selective reporting and risk of other bias.

Risk of bias assessment was carried out independently by two reviewers. After the assessment each study a decision was made for each study describing it as 'Low risk of bias' if all domains were at low risk of bias, 'Unclear risk of bias' if there was unclear risk of bias of at least one domain, and 'High risk of bias' if at least one domain was scored as being at a high risk of bias (table 2).

\section{Statistical Analyses Measures of Treatment Effect:-}

The estimate of effect of an intervention was expressed as Risk Differences (RDs) together with 95\% confidence intervals (CIs) in regard to dichotomous outcomes. Mean Differences (MDs) and standard deviations were used to summarise the data for each group with $95 \%$ CIs in regard to continuous outcomes.

Unit of Analysis:-

The framework or verification jig was considered as statistical unit. 


\section{Missing Data:-}

The missing relevant information of the included trials was requested from the corresponding authors via email and reminder emails were sent if no responses.

\section{Assessment of Heterogeneity:-}

The significance of any variations in the estimates of the treatment effects from the different trials was to be assessed by means of Cochran's test for heterogeneity, and heterogeneity would have been considered significant if $\mathrm{P}$ value $<0.1$. Heterogeneity between the studies was assessed using the I-squared statistic (I2-statistic), which describes the variation percentage due to heterogeneity rather than chance (I2 over 50\% was considered as moderate to high heterogeneity).

\section{Results:-}

The search conducted in two databases on November 2017 found 196 studies on Medline (PubMed), 88 on Cochrane. Of these, 14 articles were selected for review. An additional 2 studies were added by manual search, bringing the total up to 16 studies. After filteration by title and abstract only 3 studies were selected for the review. The selection process is summarized in a flow diagram (Figure 1). The following variables were extracted from these studies (Table 1): author, year, type of implant, total implant number, impression number, impression level, splinting methods, splinting material, impression material, type of stone, method of framework fabrication, framework level, number of frameworks, fitting test, number of subjects per study, number of subjects per group, number of frameworks per group, number of fit and miss-fit frameworks.

One study used implant with external hex (Panos Papaspyridakos et. al 2011) and the other two studies used implant with internal hex. All impressions in the three studies were taken at implant level. A. Yosry Moh et al 2012 used Ready made Acrylic bars for impression transfer splinting while the other two studies used floss and resin. A. Yosry Moh et al 2012 used Medium consistency addition silicone impression material while the other two studies used polyether impression material. All studies used stone type IV. Panos Papaspyridakos et. al fabricated the framework from Zirconia by CAD/ CAM technology. A.Yosry Moh et al 2012 fabricated a Verification jig to evaluate the passive fit. Michael Perez-Davidi et al fabricated Metal frame-work by selective laser melting of CoCrMo alloy.

Panos Papaspyridakos et. al 2011 fabricated three casts for each dental arch. The first fabricated from splinted impression (group I), the second fabricated from non-splinted impression (group II), and the third (control group) indexed from verification jig. 13 frameworks fabricated and examined clinically to assure total passive fit. Then each framework tried to its respective casts from group I and group II and the fit was examined to assess the accuracy of the fabricated casts and impression technique.

Michael Perez-Davidi et al 2016 fabricated 61 abutment level frameworks 26 with splinted technique and 29 with non-splinted technique and examined its passive fit clinically.

Yosry Moh et al 2012 fabricated 40 verification jigs for 20 dental arches in 10 completely edentulous patients.

For each edentulous arch one verification jig fabricated from splinted impression and another one fabricated from non-splinted impression.

After assessing the frameworks fitting, Panos Papaspyridakos et. al 2011 results was 12 fitted and only 1 miss fit for splinted group and 6 fitted and 7 miss fit for non-splinted group. Michael Perez-Davidi et al 2016 results was 26 fit and 3 miss fit for splinted group and 29 fit and 3 miss fit for non-splinted group. A.Yosry Moh et al 2012 results was 16 fit and 4 miss fit for splinted group while it was 6 fit and 14 miss fit for non-splinted group.

With gathering the 3 studies the total results will be 54 fit and 8 miss fit for splinted group and 41 fitted and 24 miss fit for non-splinted group. The meta-analysis of the three trials regarding framework fitting comparing splinted and non-splinted impression showed statistically non-significant more risk of misfit in none splinted technique when compared to splinted technique ( $\mathrm{I}^{2}=63 \%, \mathrm{P}=0.08$; OR: $0.22,95 \%$ CI: $\left.0.04,1.19\right)$ fig. (2) 
Figure 1:- Outlines the algorithm of the study selection procedure (PRISMA) . splinted impression non-splinted impression Odds Ratio

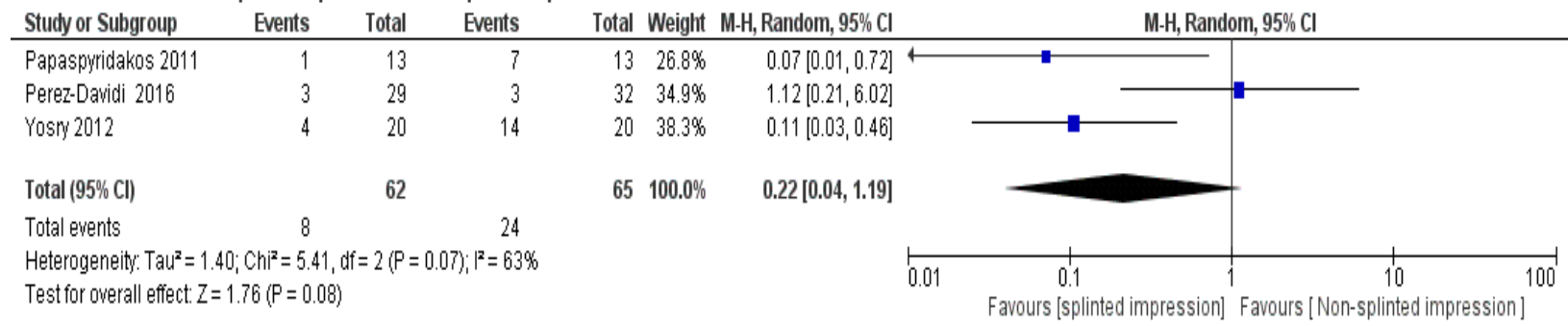

Figure 2:- Meta-analysis of the gathered data.

\begin{tabular}{|c|c|c|c|c|c|c|c|c|c|c|c|c|c|c|c|c|c|c|}
\hline \multirow{2}{*}{$\begin{array}{l}\text { Study } \\
\text { ID }\end{array}$} & \multirow[b]{2}{*}{ 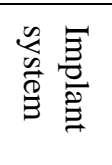 } & \multirow[b]{2}{*}{$\overrightarrow{\underline{O}}$} & \multirow[b]{2}{*}{ 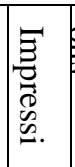 } & \multirow[b]{2}{*}{ 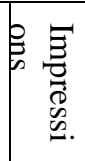 } & \multirow[b]{2}{*}{ a } & \multirow[b]{2}{*}{ 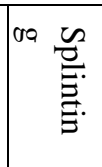 } & \multirow[b]{2}{*}{ 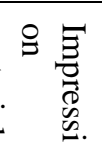 } & \multirow[b]{2}{*}{ 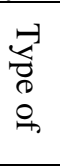 } & \multirow[b]{2}{*}{ 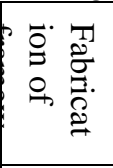 } & \multirow[b]{2}{*}{ 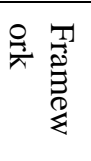 } & \multirow[b]{2}{*}{$\begin{array}{l}Z \\
0 \\
0 \\
0 \\
0\end{array}$} & \multirow[b]{2}{*}{. } & \multirow[b]{2}{*}{$\overrightarrow{0}$} & \multirow{2}{*}{\multicolumn{2}{|c|}{ 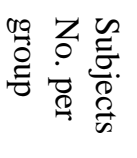 }} & \multirow[b]{2}{*}{ 疋 } & \multicolumn{2}{|c|}{ Fitting } \\
\hline & & & & & & & & & & & & & & & & & $\mathrm{F}$ & $\begin{array}{l}\text { Mis } \\
\text { s-fit }\end{array}$ \\
\hline $\begin{array}{l}\text { Panos } \\
\text { Papasp } \\
\text { yridako }\end{array}$ & $\begin{array}{l}\text { (Bran } \\
\text { emar } \\
\mathrm{k}\end{array}$ & $\begin{array}{l}8 \\
0\end{array}$ & $\begin{array}{l}1 \\
3\end{array}$ & $\begin{array}{l}\text { Im } \\
\text { pla } \\
\text { nt }\end{array}$ & $\begin{array}{l}\text { Flo } \\
\text { ss } \\
\text { and }\end{array}$ & $\begin{array}{l}\text { Ligh } \\
\text { t- } \\
\text { cure }\end{array}$ & $\begin{array}{l}\text { Polye } \\
\text { ther } \\
\text { (Impr }\end{array}$ & $\begin{array}{l}\text { T } \\
\text { yp } \\
\text { e }\end{array}$ & $\begin{array}{l}\text { CAD/ } \\
\text { CAM } \\
\text { Zirco }\end{array}$ & $\begin{array}{l}\text { Impl } \\
\text { ant } \\
\text { level }\end{array}$ & $\begin{array}{l}1 \\
3\end{array}$ & $\begin{array}{l}\text { Sin } \\
\text { gle } \\
\text { Scr }\end{array}$ & $\begin{array}{l}1 \\
2\end{array}$ & $\begin{array}{l}\text { spli } \\
\text { nte } \\
\text { d }\end{array}$ & $\begin{array}{l}1 \\
2\end{array}$ & $\begin{array}{l}1 \\
3\end{array}$ & $\begin{array}{l}1 \\
2\end{array}$ & 1 \\
\hline $\begin{array}{l}\text { s et. al } \\
2011^{(22)}\end{array}$ & $\begin{array}{l}\text { Syste } \\
\mathrm{m}, \\
\text { Nobe } \\
1 \\
\text { Bioca } \\
\text { re) } \\
\text { (Exte } \\
\text { rnal } \\
\text { Hex) }\end{array}$ & & & $\begin{array}{l}\text { lev } \\
\text { el }\end{array}$ & $\begin{array}{l}\text { resi } \\
\mathrm{n}\end{array}$ & $\begin{array}{l}\text { resin } \\
\text { (Tri } \\
\text { ad } \\
\text { gel, } \\
\text { Dent } \\
\text { sply } \\
\text { ) }\end{array}$ & $\begin{array}{l}\text { egum } \\
\text {,3M } \\
\text { ESPE } \\
\text { ) }\end{array}$ & $\begin{array}{l}\mathrm{I} \\
\mathrm{V}\end{array}$ & nia & & & $\begin{array}{l}\text { ew } \\
\text { Te } \\
\text { st }\end{array}$ & & $\begin{array}{l}\text { No } \\
n\end{array}$ & $\begin{array}{l}1 \\
2\end{array}$ & $\begin{array}{l}1 \\
3\end{array}$ & 6 & 7 \\
\hline $\begin{array}{l}\text { Michae } \\
1 \text { Perez- } \\
\text { Davidi }\end{array}$ & $\begin{array}{l}\text { MIS } \\
\text { Impla } \\
\text { nt }\end{array}$ & $\begin{array}{l}2 \\
1 \\
3\end{array}$ & $\begin{array}{l}6 \\
1\end{array}$ & $\begin{array}{l}\text { Im } \\
\text { pla } \\
\text { nt }\end{array}$ & $\begin{array}{l}\text { Flo } \\
\text { ss } \\
\text { and }\end{array}$ & $\begin{array}{l}\text { Patt } \\
\text { ern } \\
\text { resin }\end{array}$ & $\begin{array}{l}\text { (Impr } \\
\text { egum } \\
, 3 \mathrm{M}\end{array}$ & $\begin{array}{l}\text { T } \\
\text { yp } \\
\text { e }\end{array}$ & $\begin{array}{l}\text { Metal } \\
\text { frame } \\
\text {-work }\end{array}$ & $\begin{array}{l}\text { Abu } \\
\text { tme } \\
\text { nt }\end{array}$ & $\begin{array}{l}6 \\
1\end{array}$ & $\begin{array}{l}\mathrm{Di} \\
\text { git } \\
\text { al }\end{array}$ & $\begin{array}{l}5 \\
5\end{array}$ & $\begin{array}{l}\text { spli } \\
\text { nte } \\
\text { d }\end{array}$ & $\begin{array}{l}2 \\
6\end{array}$ & $\begin{array}{l}2 \\
9\end{array}$ & $\begin{array}{l}2 \\
6\end{array}$ & 3 \\
\hline $\begin{array}{l}\text { et al } \\
2016^{(23)}\end{array}$ & $\begin{array}{l}\text { (inter } \\
\text { nal } \\
\text { Hex) }\end{array}$ & & & $\begin{array}{l}\text { lev } \\
\text { el }\end{array}$ & $\begin{array}{l}\text { resi } \\
\mathrm{n}\end{array}$ & $\begin{array}{l}(\mathrm{GC} \\
\text { Ame } \\
\text { rica) }\end{array}$ & $\begin{array}{l}\text { ESPE } \\
\text { ) }\end{array}$ & $\begin{array}{l}\mathrm{I} \\
\mathrm{V}\end{array}$ & $\begin{array}{l}\text { (selec } \\
\text { tive } \\
\text { laser } \\
\text { melti } \\
\text { ng of } \\
\text { CoCr } \\
\text { Mo } \\
\text { alloy) }\end{array}$ & level & & $\begin{array}{l}\text { per } \\
\text { i- } \\
\text { api } \\
\text { cal } \\
\text { X- } \\
\text { ray }\end{array}$ & & $\begin{array}{l}\text { No } \\
n\end{array}$ & $\begin{array}{l}2 \\
9\end{array}$ & $\begin{array}{l}3 \\
2\end{array}$ & $\begin{array}{l}2 \\
9\end{array}$ & 3 \\
\hline $\begin{array}{l}\text { A.Yosr } \\
\text { y Moh } \\
\text { et al }\end{array}$ & $\begin{array}{l}\text { Denti } \\
\text { s, } \\
\text { Kore }\end{array}$ & $\begin{array}{l}8 \\
0\end{array}$ & $\begin{array}{l}4 \\
0\end{array}$ & $\begin{array}{l}\text { Im } \\
\text { pla } \\
\text { nt }\end{array}$ & $\begin{array}{l}\text { Re } \\
\text { ady } \\
\text { ma }\end{array}$ & $\begin{array}{l}\text { Acr } \\
\text { ylic } \\
\text { resin }\end{array}$ & $\begin{array}{l}\text { Medi } \\
\text { um } \\
\text { consi }\end{array}$ & $\begin{array}{l}\text { T } \\
\text { yp } \\
\text { e }\end{array}$ & $\begin{array}{l}\text { Verifi } \\
\text { catio } \\
\mathrm{n} \text { jig }\end{array}$ & $\begin{array}{l}\text { Impl } \\
\text { ant } \\
\text { level }\end{array}$ & $\begin{array}{l}4 \\
0\end{array}$ & $\begin{array}{l}\text { Sin } \\
\text { gle } \\
\text { Scr }\end{array}$ & $\begin{array}{l}1 \\
0\end{array}$ & $\begin{array}{l}\text { Spli } \\
\text { nte } \\
\text { d }\end{array}$ & $\begin{array}{l}1 \\
0\end{array}$ & $\begin{array}{l}2 \\
0\end{array}$ & $\begin{array}{l}1 \\
6\end{array}$ & 4 \\
\hline $2012^{(24)}$ & $\mathrm{a}$ & & & $\begin{array}{l}\text { lev } \\
\text { el }\end{array}$ & $\begin{array}{l}\mathrm{de} \\
\text { Ac } \\
\text { ryli } \\
\mathrm{c} \\
\text { bar } \\
\mathrm{s}\end{array}$ & $\begin{array}{l}\text { and } \\
\text { Dur } \\
\text { alay }\end{array}$ & $\begin{array}{l}\text { stenc } \\
\text { y } \\
\text { additi } \\
\text { on } \\
\text { silico } \\
\text { ne, } \\
\text { elite } \\
\text { HD+, } \\
\text { Zher } \\
\text { mack } \\
\text {, Italy }\end{array}$ & $\begin{array}{l}\mathrm{I} \\
\mathrm{V}\end{array}$ & & & & $\begin{array}{l}\text { ew } \\
\text { Te } \\
\text { st }\end{array}$ & & non & $\begin{array}{l}1 \\
0\end{array}$ & $\begin{array}{l}2 \\
0\end{array}$ & 6 & 14 \\
\hline Total & & $\begin{array}{l}3 \\
7 \\
\end{array}$ & $\begin{array}{l}1 \\
1\end{array}$ & & & & & & & & $\begin{array}{l}1 \\
1\end{array}$ & & $\begin{array}{l}7 \\
7 \\
\end{array}$ & & & & & \\
\hline
\end{tabular}




\section{\begin{tabular}{l|l|l|l|l|l|}
3 & 4 & & & \\
\hline
\end{tabular}}

Table 1:- summarised included studies details.

Table 1:- Risk Of Bias Assessment Of The Included Rcts.

\begin{tabular}{|c|l|l|l|l|l|l|l|}
\hline Study ID & $\begin{array}{l}\text { Random } \\
\text { sequence } \\
\text { generation }\end{array}$ & $\begin{array}{l}\text { Allocation } \\
\text { concealment }\end{array}$ & $\begin{array}{l}\text { Blinding of } \\
\text { outcome } \\
\text { assessment }\end{array}$ & $\begin{array}{l}\text { Incomplete } \\
\text { outcome data }\end{array}$ & $\begin{array}{l}\text { Selective } \\
\text { reporting }\end{array}$ & $\begin{array}{l}\text { Other } \\
\text { bias }\end{array}$ & $\begin{array}{l}\text { Overall } \\
\text { risk }\end{array}$ \\
\hline $\begin{array}{c}\text { Panos } \\
\text { Papaspyridakos } \\
\text { et. al 2011 }\end{array}$ & Low & Low & low & low & Low & Low & low \\
\hline $\begin{array}{c}\text { A.Yosry Moh et } \\
\text { al 2012 }\end{array}$ & Low & low & Unclear & Low & Low & Low & High \\
\hline $\begin{array}{c}\text { Michael Perez- } \\
\text { Davidi et al } \\
\text { 2016 }\end{array}$ & High & High & High & Low & Low & Low & High \\
\hline
\end{tabular}

\section{Discussion:-}

This review gathered studies clinically evaluated accuracy of splinted and non-splinted implant impression techniques by detecting the passive fit of frameworks fabricated from both techniques. In addition, it provided metaanalysis of the data extracted from these studies. This review aims to help clinicians to select impression technique that provide better accuracy and better fit of the prosthesis.

Two studies Panos Papaspyridakos et. al 2011 and A.Yosry Moh et al 2012 demonistrated better fit with splinted impression technique. While Michael Perez-Davidi et al 2016 showed close results with both techniques. The gathered data indicated statistically non-significant more risk of misfit in none splinted technique when compared to splinted technique. The result of this review is not in agreement with several studies which revealed the superiority of the splinted technique. ${ }^{15-16-17-18}$ Other studies in agreement with the results of this review have stated that both impression techniques provide comparable results. ${ }^{19-20-21}$

Number of studies clinically evaluated accuracy of splinted and non-splinted implant impression is low compared with the in-vitro studies in the same field so that, it is important to gather the clinical trials as there is many clinical factors that affect accuracy of implant impressions that can't be simulated in the in-vitro studies such as functional elastic deformation of the jaws during different mandibular movements. ${ }^{(13-14)}$

The included studies used common and applicable coping splinting techniques which are frequently used in practice. Panos Papaspyridakos et. al 2011 and Michael Perez-Davidi et al 2016 used dental floss and resin to splint the impression copings while A.Yosry Moh et al 2012 used ready made acrylic bars for this purpose.

\section{Conclusion:-}

Within the limitation of this review, splinted impression technique provide better passive fit than nonsplinted impression technique with no significant difference.

\section{References:-}

1. Goll GE. Production of accurately fitting full-arch implant frameworks: Part I-Clinical procedures. J Prosthet Dent. 1991;66:377-384.

2. Kallus T, Bessing C. Loose gold screws frequently occur in fullarch fixed prostheses supported by oseointegrated implants after 5 years. Int J Oral Maxillofac Implants. 1994;9:169-178.

3. Humphries RM, Yaman P, Bloem TJ. The accuracy of implant master casts constructed from transfer impressions. Int J Oral Maxillofac Implants. 1990;5:331-336.

4. Henry PJ. An alternative method for the production of accurate casts and occlusal records in osseointegrated implant rehabilitation. J Prosthet Dent. 1987;58:694-697.

5. Branemark PI, Zarb GA, Albrektsson T. Tissue-integrated prostheses. Osseointegration in clinical dentistry. Chicago: Quintessence; 1985. pp. 11-12.pp. 253-257.

6. Inturregui JA, Aquilino SA, Ryther JS, Lund PS. Evaluation of three impression techniques for osseointegrated oral implants. J Prosthet Dent. 1993;69:503-509. 
7. Burawi G, Houston F, Byrne D, Claffey N. A comparison of the dimensional accuracy of the splinted and unsplinted impression techniques for the Bone-Lock implant system. J Prosthet Dent. 1997;77:68-75

8. Cabral LM, Guedes CG. Comparative analysis of 4 impression techniques for implants. Implant Dent. 2007;16:187-194.

9. Del'Acqua MA, Arioli-Filho JN, Compagnoni MA, Mollo FA Jr. Accuracy of impression and pouring techniques for an implant-supported prosthesis. Int J Oral Maxillofac Implants 2008;23:226-36.

10. Rangert B, Jemt T, Jörneus L. Forces and moments on Branemark implants. Int J Oral Maxillofac Implants. 1989;4:241-247.

11. Tan KB, Rubenstein JE, Nicholls JI, Yuodelis RA. Three-dimensional analysis of the casting accuracy of onepiece, osseointegrated implant-retained prostheses. Int J Prosthodont. 1993;6:346-363.

12. Moher, D; Liberati, A; Tetzlaff, J; and DG Altman. 2010. "Preferred Reporting Items for Systematic Reviews and Meta-Analyses: The PRISMA Statement... Preferred Reporting Items for Systematic Reviews and MetaAnalyses." BMJ: British Medical Journal (Overseas $\{\&\}$ Retired Doctors Edition) 8 (5): b2535. doi:10.1016/j.ijsu.2010.02.007.

13. Law, C., Bennani, V., Lyons, K., and Swain, M., Influence of implant framework and mandibular flexure on the strain distribution on a Kennedy class II mandible restored with a long-span implant fixed restoration: a pilot study. J Prosthet Dent, 2014.

14. Chen, D.C., Lai, Y.L., Chi, L.Y., and Lee, S.Y., Contributing factors of mandibular deformation during mouth opening. J Dent, 2000. 28(8): p. 583-8.

15. Naconecy MM, Teixeira ER, Shinkai RS, Frasca LC, Cervieri A. Evaluation of the accuracy of 3 transfer techniques for implant- supported prostheses with multiple abutments. Int J Oral Maxillofac Implants 2004;19:192-8.

16. Vigolo P, Fonzi F, Majzoub Z, Cordioli G. An evaluation of impression techniques for multiple internal connection implant prostheses. J Prosthet Dent 2004;92:470-6

17. Assuncao WG, Filho HG, Zaniquelli O. Evaluation of transfer impressions for osseointegrated implants at various angulations. Implant Dent 2004;13:358-66

18. Cabral LM, Guedes CG. Comparative analysis of 4 impression techniques for implants. Implant Dent 2007; $16: 187-94$

19. Kim S, Nicholls JI, Han CH, Lee KW. Displacement of implant components from impressions to definitive casts. Int J Oral Maxillofac Implants 2006;21:747-55.I

20. Choi JH, Lim YJ, Yim SH, Kim CW. Evaluation of the accuracy of implant-level impression techniques for internal-connection implant prostheses in parallel and divergent models. Int $\mathbf{J}$ Oral Maxillofac Implants 2007;22:761-8

21. Del'Acqua MA, Arioli-Filho JN, Compagnoni MA, Mollo Fd A Jr. Accuracy of impression and pouring techniques for an implant-supported prosthesis. Int J Oral Maxillofac Implants. 2008;23:226-36.

22. Panos Papaspyridakos, Kunal Lal, George Shelby White, Hans-Peter Weber, German O Gallucci. Effect of splinted and nonsplinted Impression Techniques on the Accuracy of fit of fixed implant prostheses in Edentulous Patients: A Comparative study. Int J Oral Maxillofac Implants. 2011; 26;1267-1272.

23. Michael Perez-Davidi, Michael Levit, Ofer Walter, Yuval Eilat, Peter Rosenfeld. Clinical accuracy outcomes of splinted and nonsplinted implant impression methods in dental residency settings. Quintessence Int J Prosth. 2016;47;843-852.

24. A.Yosry Moh., EL Far Mahm., EL Khadem Amr. The effect of two impression techniques on the fit of screw retained implant frameworks. MDS thesis, Faculty of dentistry, Cairo University. 2012. 